\title{
Post Scriptum
}

Post Scriptum

\author{
Hilda Sabato \\ Professora na Faculdade de \\ Filosofia e Letras da Universidade \\ de Buenos Aires (UBA) e \\ pesquisadora do Conselho Nacional \\ de Investigações Científicas e \\ Tecnológicas (CONICET - Argentina) \\ e-mail: hsabato@arnet.com.ar
}

\section{Resumo}

Este texto propõe continuar o diálogo iniciado pelos comentários de Miriam Dolhnikoff e Bernardo Ricupero sobre o meu ensaio intitulado "Soberania popular, cidadania e nação na América Hispânica: a experiência republicana do século XIX". Ele não pretende abranger o amplo campo aberto pelas reflexões e questões dos historiadores, mas apenas avançar na discussão de quatro dos temas por eles colocados: a comparação da experiência política das repúblicas hispano-americanas com a da monarquia constitucional brasileira; o contraponto entre a história da cidadania na América Hispânica e a de alguns paises da Europa, e a pertinência do chamado "modelo de Marshall" para o caso latino-americano; o funcionamento de certas práticas políticas específicas e, em particular, as vinculadas com as eleições; e o processo de formação e transformação das elites políticas ao longo do século XIX.

\section{Abstract}

The purpose of these pages is to continue the dialogue started by Miriam Dolhnikoff's and Bernardo Ricupero's commentaries to my essay on "Popular Sovereignty, Citizenship, and Nation-Building in Nineteenth Century Spanish America: The Republican Experiment". I will not try here to cover the vast field opened by their thoughtful reflections and remarks, but rather to advance in the discussion of four of the themes they raise: the comparison between the political experience of the Hispanic-American republics and that of the Brazilian constitutional monarchy; the contrast between the history of citizenship in Spanish America and that of several European countries, and the relevance of Marshall's model of citizenship to the Latin American case; the development of specific political practices, particularly those pertaining to elections; and the process of formation and transformation of the political elites in the course of the nineteenth century.

\section{Palavras-chave}

cidadania, república / republicanismo, práticas políticas, nação, América espanhola, representações políticas

\section{Keywords}

citizenship, republic / republicanism, political practices, nation, Spanish America, political representations 
Agradeço a oportunidade oferecida pelos sugestivos comentários de Miriam Dolhnikoff e Bernardo Ricupero para iniciar um diálogo que, sem dúvidas, será muito próspero. Eles colocaram uma série de questões para continuar refletindo sobre as propostas formuladas e para explorar outras novas. Não pretendo abranger aqui o amplo campo que ficou em aberto, mas apenas aproveitar a ocasião para avançar no nosso intercâmbio.

Vou começar com uma comparação básica, que pode ser estabelecida entre a história das repúblicas hispano-americanas e a da monarquia brasileira. Tal como coloca Miriam, a adoção do regime de monarquia constitucional no Império do Brasil também implicou na instauração do princípio de soberania popular como fundamento do poder político assim como a criação e o funcionamento de instituições muito semelhantes às instauradas no resto da América Ibérica. Portanto, eu considero que todos e cada um dos temas abordados no meu ensaio são pertinentes para o estudo da história política do Brasil do século XIX. De fato, os historiadores de ambas as partes têm trabalhado nas mesmas questões e poderíamos, com certa facilidade, incorporar o caso do Brasil para nossa comparação. Gostaria de acrescentar também que na minha menção sobre a dimensão latinoamericana de nossa historiografia mais recente eu tenho incluido sem duvida a brasileira, porque ela é fundamental não somente pelos aportes sobre o caso em particular, mas também pela sua reflexão mais geral sobre a questão da cidadania em suas diferentes fases. Para o propósito de meu ensaio, porém, existe uma clara diferença entre o Brasil e as outras nações, pois embora a instauração da monarquia no Brasil foi constitucional, afetou de um modo decisivo o princípio de igualdade. A existência de uma desigualdade originária na pessoa do imperador implicou, simbólica e materialmente, em bases diferentes às estabelecidas nas repúblicas, tanto para a definição da legitimidade, quanto para a construção do poder político. Portanto, e dado que o foco da minha indagação está colocado precisamente nos problemas da igualdade e desigualdade política, e nos limites de inclusão e exclusão da polis, decidi desconsiderar o caso do Brasil, que já fora incorporado em trabalhos anteriores onde analisei o conjunto das experiências nacionais da região.

Uma segunda questão se refere à comparação com o desenvolvimento da cidadania em países da Europa e a pertinência do chamado "modelo de Marshall" para a nossa história. A influência do trabalho do sociólogo inglês foi, sem dúvida, decisiva nas interpretações canônicas sobre a cidadania e suas transformações. 0 mesmo tem acontecido nas discussões mais recentes sobre o tema. A referência e as críticas a esse modelo constituem um ponto de partida iniludivel na hora de explorar a história política da América Latina. Da minha parte, considero que - além da distância que hoje possamos encontrar em sua proposta de desenvolvimento gradual e progressivo dos direitos dos cidadãos -, o seu trabalho permite explorar o problema das relações entre igualdade e desigualdade nas nações modernas. Porém, não acho que, tal como sugere Bernardo, esse problema seja da América Latina em termos de mudança política versus continuidade, ou imobilidade da estrutura econômica e social. As revoluções de independência desataram transformações profundas em todos os planos e nada foi igual àquilo que tinha sido em tempos coloniais. E o nosso desafio consiste precisamente em explorar e dar conta dessas mudanças. No plano da política, minha hipótese é que a incorporação do princípio de igualdade dos direitos transformou as relações entre os homens e gerou 
um processo muito intenso de inclusão na vida política. Mas, sublinho, o mesmo processo produziu e reproduziu desigualdades e hierarquias novas, que deram um novo tom para a república do século XIX.

Esta questão me conduz para o terceiro ponto de meus comentários para os "Comentários", o qual se refere a certas práticas políticas específicas e, em particular, às vinculadas com as eleições. No meu texto eu só sintetizei de um modo bem conciso um tema amplo que foi matéria de estudos pormenorizados, profundos, que deram conta de uma diversidade de situações e da complexidade das relações estabelecidas em torno dessa dimensão da vida política. Portanto, haveria muito mais para se falar nesse tópico, mas aqui vou me limitar apenas a duas questões surgidas do comentário de Miriam. A primeira remete à amplitude do direito eleitoral em quase todo o território ibero-americano, tema em que a comparação com a Europa e os Estados Unidos é inevitável. Apesar do interesse que tem despertado entre os historiadores, não existem respostas coincidentes sobre esse assunto. Talvez não devêssemos esperar por elas, porque possivelmente a persistência de um sufrágio masculino amplo respondeu a causas diferentes, em diferentes momentos e locais. A definição mesma do cidadão ideal foi mudando com o tempo, e também mudaram as normas reguladoras do sufrágio e as práticas de seu exercício. A afirmação acerca do caráter extensivo do voto apenas mostra um traço compartilhado que teve conseqüências importantes na hora da incorporação politica, mas que não é suficiente para explicar seus alcances e seus limites, suas mudanças e persistências.

A segunda questão que me interessa comentar é a que se refere à fraude eleitoral. Tal como perceptivamente aponta Miriam, a maior parte das referências contemporâneas para a fraude são provenientes de relatos interesseiros. Com efeito, foram os perdedores da ocasião os que primeiro levantaram a acusação de fraude para invalidar os resultados eleitorais nos quais a sorte tinha sido adversa. A partir destes depoimentos, e de uma visão prescritiva do sistema eleitoral que projetava para trás os critérios presentes para julgar fatos do passado, durante anos os historiadores desconsideraram a importância das eleições do século XIX em termos de representação política e do exercício da soberania popular. Nas últimas décadas, porém, tanto na América Latina, quanto na Europa e nos Estados Unidos, veio à tona o papel das eleições na vida política oitocentista e tem se procurado compreendê-las na sua especificidade e dinâmica. Mais do que desqualificar as eleições por não responderem a modelos prefixados de comportamento desejável, os estudos atuais procuram descobrir como funcionavam os sistemas e os mecanismos eleitorais concretos, em relação tanto à representação, como à participação política. Dentro desse contexto, a palavra "fraude" não se torna muito útil para a descrição ou a análise histórica, porque carrega uma forte conotação negativa, própria da época em que foi criada. No entanto, é de referência inevitável na hora de explorar as representações que os próprios contemporâneos desdobravam sobre as eleições: como e quando falavam de "fraude", o que estava sendo aludido com esse termo e como era articulado com outros conceitos da linguagem política da época.

Para concluir, uma menção à última pergunta de Miriam, a respeito de minhas considerações sobre os dirigentes políticos. Também nesse ponto pretendi chamar a atenção sobre as novidades trazidas pelas revoluções de independência e a adoção de formas republicanas de governo 
que abriram o caminho para o que eu denomino de um "fantástico processo de redefinição, reelaboração e ampliação" das elites políticas. Essa mudança implicou, entre outras coisas, na formação de novos dirigentes que nasceram e construíram seu lugar a partir de sua capacidade para a ação nos terrenos recém abertos: primeiro o da guerra e, logo depois, o das novas instituições e práticas. A própria esfera política foi constituída como um espaço de geração e acumulação de poder, que não necessariamente dependia do capital social ou econômico prévio dos atores. A existência destas trajetórias possíveis não impediu, certamente, que existissem vinculos entre os que ganhavam poder político e os que o ostentavam em outras esferas da vida social. Mas essa relação não era de identificação necessária, nem de superposição estrita e, portanto, mais do que ser adotada como uma suposta premissa, deveria ser motivo de questionamento e estudo para cada caso em particular.

Tal como vemos, a intensidade e a complexidade da vida política no republicano século XIX afetaram tanto às elites como o resto da população da América Hispânica e transformaram para sempre seus lugares no mundo. Fica para nós, historiadores do século XXI, continuar explorando, interpretando e discutindo como foram essas mudanças.

Tradução: Marisa Montrucchio 